\title{
Environmental assessment of the production process of internal combustion engines
}

The aim of this article is to demonstrate using the LCA methodology the environmental effects of material composition changes on Volkswagen Golf passenger cars over the past 30 years. The simplified LCA model of the engine presented in the work shows the energy consumption and total $\mathrm{CO}_{2}$ emissions based on the mass of materials. It was built to investigate general assumptions about material production and car recycling. The results of the research presented in the paper give an image of the modernity of a passenger car engine on the basis of consumption and the degree of recovery of materials used for its construction.

Key words: car, combustion engine, LCA, eco-design, production

\section{Introduction}

The most complex product of mass industrial production is a passenger car.It consists of thousands of parts made of almost all kinds of materials such as metals, aluminum and its alloys, plastics, glass and ceramics. Car production currently has a significant impact on the environment. The choice of more environmentally friendly construction materials from which it is manufactured can significantly reduce its environmental impact. The main component of each vehicle is the car engine. In the past, car engines were mainly designed for high performance, which caused that environmental pollution by motor vehicles became a significant problem in the second half of the 20th century and today. Since then, the development of environmental requirements has become a major factor stimulating the development of modern engine designs.

Currently the strategic goal of the European Union's energy policy in the transport sector is to reduce greenhouse gas emissions by $60 \%$ by 2050 compared to the levels from 1990. One way to achieve this is to strive for a more sustainable use of all means of transport due to the fact that this sector represents a major and still growing source of greenhouse gas emissions. That forces manufacturers to improve the energy efficiency of vehicles through the introduction of new technologies, especially in the field of drive systems. The effects of concern for the environment are visible - the unit emissions of pollutants in the exhaust fumes from new cars are reduced. Already at the beginning of the 1950s, Californian researchers for the first time linked environmental pollution to vehicle traffic. There, the first emission standards were introduced. Since then, the development of environmental requirements has become a majorfactor stimulating the development of modern engine designs $[1,2]$.

The traditional approach to environmental assessment of a car is first of all to determine pollutants and $\mathrm{CO}_{2}$ emissions, which depend on the type and amount of fuel consumed. Research methods of the sizes are largely objectified, have a long tradition in the automotive industry and are based on extensive knowledge. The result of this approach are existing emission standards. The Life Cycle Method (LCA) described in ISO 14040 [3] and 14044 [4] expresses a contemporary approach to the problem of the impact of a car and its components on the environment.
These standards define comprehensive, quantitative determination of an environmental load, based on the inventory of environmental factors associated with the object, process or other activity throughout the cycle from extracting raw materials to their final disposal [5-8]. The LCA method, introduced since the 1970s $[9,10]$, is one of the most effective and reliable eco-balance tools for assessing the amount of energy consumption and the volume of emissions of hazardous substances and materials in all phases of a product existence - from raw materials acquisition to liquidation of exploited products [11]. This is the basis for estimating the available options in order to reduce the load into the environment $[5,6]$.

\section{Modeling of the engine life cycle}

\subsection{Purpose and scope of research}

Current requirements for construction materials used in the automotive industry is primarily a tendency to use materials with lower density and greater strength and better performance. This makes it possible to reduce the weight of the vehicle and thus reduce fuel consumption so that the vehicle's carbon emissions to the environment are reduced. The use of new construction and operating materials, as well as a technology of a vehicle manufacturing and service, should help to increase the durability of vehicles and their components and extend the service intervals.

This reduces the environmental load of waste materials associated with the handling and disposal of end-of-life vehicles. The benefit is also the saving of raw materials and energy needed to process materials and produce parts and assemblies of vehicles. New construction materials and vehicle design itself should be adapted to the efficient recycling of vehicles. It is therefore necessary to optimize the design of cars, taking into account the issues of material selection and recycling at the design stage.

In the article, the LCA method was used to compare the environmental profiles of six spark-ignition internal combustion engines with similar operating characteristics produced in the last 30 years. The main objective of these studies was to assess the environmental effects of using different construction materials in engines [14, 15]. This assessment takes into account the use of recycled materials. A recycling scenario has been adopted in which materials recovered from end-of-life vehicles go back into the pro- 
duction cycle of materials as a secondary raw material (closed loop recycling). In this way, recycling replaces primary raw materials and the impact of primary raw material production on the environment is avoided.

The research was conducted in accordance with the LCA method described in the Europe standards. Environmental impact is presented in the form of energy flows and total pollutant emissions with significant potential for global warming.

The results relate to six generations of the Volkswagen Golf petrol engine with similar exhaust gas operating characteristics, produced in the last 30 years (Table 1).

Table 1. Technical specifications of tested Volkswagen Golf cars

\begin{tabular}{|l|c|c|c|c|c|c|}
\hline Model & $\begin{array}{c}\text { Golf } \\
\text { Mk1 }\end{array}$ & $\begin{array}{c}\text { Golf } \\
\text { Mk2 }\end{array}$ & $\begin{array}{c}\text { Golf } \\
\text { Mk3 }\end{array}$ & $\begin{array}{c}\text { Golf } \\
\text { Mk4 }\end{array}$ & $\begin{array}{c}\text { Golf } \\
\text { Mk5 }\end{array}$ & $\begin{array}{c}\text { Golf } \\
\text { Mk6 }\end{array}$ \\
\hline $\begin{array}{l}\text { Year } \\
\text { of construction }\end{array}$ & $\begin{array}{c}1976- \\
1983\end{array}$ & $\begin{array}{c}1983- \\
1987\end{array}$ & $\begin{array}{c}1991- \\
1997\end{array}$ & $\begin{array}{c}1997- \\
2003\end{array}$ & $\begin{array}{c}2006- \\
2008\end{array}$ & $\begin{array}{c}2008- \\
2012\end{array}$ \\
\hline Kerb weight $[\mathrm{kg}]$ & 830 & 875 & 1030 & 1174 & 1153 & 1215 \\
\hline Engine capacity $\left[\mathrm{cm}^{3}\right]$ & 1272 & 1272 & 1391 & 1390 & 1390 & 1390 \\
\hline $\begin{array}{l}\text { Average fuel consump- } \\
\text { tion NEDC }[1 / 100 \mathrm{~km}]\end{array}$ & 7.8 & 6.1 & 6.8 & 6.4 & 6.8 & 6.4 \\
\hline
\end{tabular}

\subsection{Data sources}

Material data of the VW Golf internal combustion engines was obtained during tests conducted at a certified vehicle dismantling station in Szczecin and using the most recent data from the literature. During the research, the cars were dismantled into assemblies and single parts.In order to draw up the list of materials used in the engine, the parts were weighed and the type of the material was determined. Many small parts were made from one material and in a similar technology. In this case, the list of parts was determined by the total weight in kilograms.

The list of the parts, along with information about the material weight, was used to build the LCA model of the car. As the parts are made from different materials, to simplify the model and facilitate the presentation of the life cycle assessment results, materials were assigned to five material groups:

- steel, cast steel, cast iron,

- aluminum and its alloys,

- plastics and rubber,

- non-ferrous metals,

- other materials.

The list of materials used in the Golf car engines is shown in Table 2.

Table 2. Percentage share of Volkswagen Golf engine materials

\begin{tabular}{|l|c|c|c|c|c|c|}
\hline Model & $\begin{array}{c}\text { Golf } \\
\text { Mk1 }\end{array}$ & $\begin{array}{c}\text { Golf } \\
\text { Mk2 }\end{array}$ & $\begin{array}{c}\text { Golf } \\
\text { Mk3 }\end{array}$ & $\begin{array}{c}\text { Golf } \\
\text { Mk4 }\end{array}$ & $\begin{array}{c}\text { Golf } \\
\text { Mk5 }\end{array}$ & $\begin{array}{c}\text { Golf } \\
\text { Mk6 }\end{array}$ \\
\hline $\begin{array}{l}\text { Year } \\
\text { of construction }\end{array}$ & $\begin{array}{c}1976- \\
1983\end{array}$ & $\begin{array}{c}1983- \\
1987\end{array}$ & $\begin{array}{c}1991- \\
1997\end{array}$ & $\begin{array}{c}1997- \\
2003\end{array}$ & $\begin{array}{c}2006- \\
2008\end{array}$ & $\begin{array}{c}2008- \\
2012\end{array}$ \\
\hline $\begin{array}{l}\text { Steel, cast steel, } \\
\text { cast iron }\end{array}$ & 58.4 & 59.4 & 53.3 & 52.7 & 50.0 & 49.8 \\
\hline $\begin{array}{l}\text { Aluminum and its } \\
\text { alloys }\end{array}$ & 28.6 & 28.1 & 25.3 & 25.2 & 26.7 & 26.9 \\
\hline Plastics and rubber & 2.6 & 3.0 & 7.8 & 8.2 & 8.6 & 10.2 \\
\hline Non-ferrous metals & 2.2 & 2.1 & 4.9 & 5.9 & 6.3 & 6.3 \\
\hline Other materials & 8.2 & 7.4 & 8.7 & 8.0 & 8.4 & 6.8 \\
\hline
\end{tabular}

An inventory of the impact of the production processes of these materials is shown in Figure 1. Inputs include the streams of materials used in the engine that come from the natural environment (primary production) $M_{1}, M_{2}, \ldots, M_{n}$ and from recycling (secondary production) $\mathrm{M}_{\mathrm{R} 1}, \mathrm{M}_{\mathrm{R} 2}, \ldots$, $\mathrm{M}_{\mathrm{Rn}}$. The system outputs include pollutant emissions $\mathrm{P}_{1}, \mathrm{P}_{2}$, $\ldots, \mathrm{P}_{\mathrm{n}}$ and energy consumption $\mathrm{E}_{1}, \mathrm{E}_{2}, \ldots, \mathrm{E}_{\mathrm{n}}$ associated with their generation.

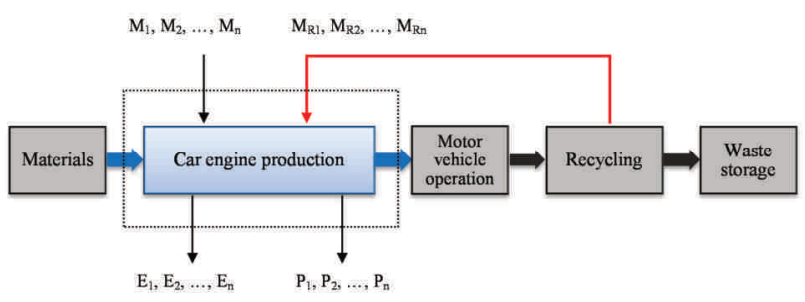

Fig. 1. Inventory of the car's life cycle

For each material stream, the volume of emissions of the substance was determined, i.e. $\mathrm{CO}, \mathrm{CO}_{2}, \mathrm{CH}_{4}, \mathrm{~N}_{2} \mathrm{O}$, $\mathrm{NO}_{\mathrm{x}}, \mathrm{NMVOC}$, which accompany primary and secondary production of materials.Data regarding the size of these emissions was obtained from the Ecoinvent 2.1 database, which is widely used in life-cycle studies. The environmental impact of these variables was converted into $\mathrm{CO}_{2 \mathrm{eq}}$ carbon dioxide emissions.Eco-Indicator EI99 E/A Europe was used for the conversion. In the LCA studies, the total $\mathrm{CO}_{2 \mathrm{eq}}$ emission was treated as an environmental impact category. While the energy consumption in the production processes of materials was specified on the basis of Gemis and Raport LCA Plastics Europe and from the assisting calculation programs: SimaPro oraz Greet.

\section{Evaluation results of engine production process}

Material data obtained reflects changes in the design of the internal combustion engine of the car. It is therefore necessary to assess whether the presented tendencies of these changes are justified from the point of view of the impact of the materials on the environment.

\subsection{Changes in the use of materials}

The material data presented in Figure 2 reflects the general tendency to increase the mass of new cars.

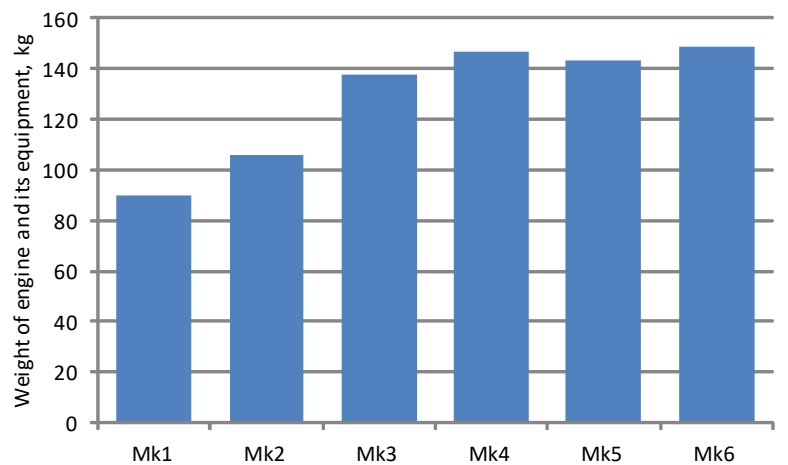

Fig. 2. Weight of Volkswagen Golf engine and its equipment 
Weight of the engineand its equipment increased by over $65 \%$ between models Mk1and Mk6. Table 2 shows a decrease in the share of steel, cast steel and cast iron in the engine construction by $8.5 \%$ between Mk1 and Mk6, with an almost four-fold increase in the share of plastics and rubber and nearly three-fold increase in the share of non-ferrous metals.

\subsection{Impact of primary production of materials}

This chapter presents the results of the environmental assessment of engines based on the energy inputs and carbon dioxide $\left(\mathrm{CO}_{2}\right)$ emissions associated with the primary production of the materials. The comparison of environmental loads for the individual materials of the car engine is shown in Figures 3 and 4.

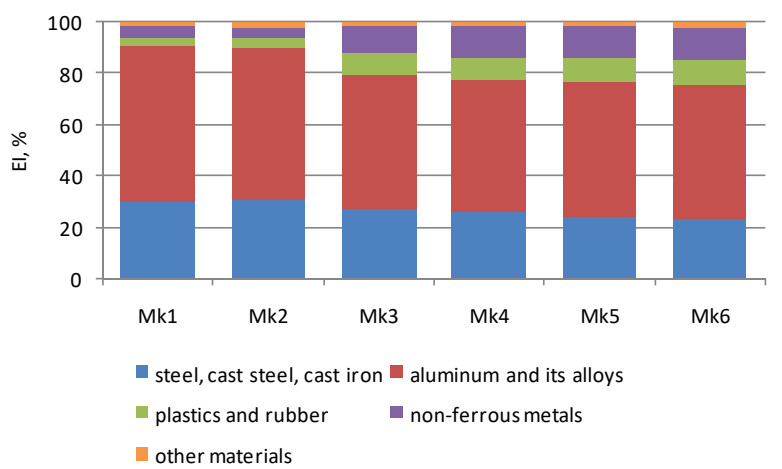

Fig. 3. Percentage share of energy inputs for the Volkswagen Golf engine and its equipment divided into materials

Based on the results of the assessment, the dominant share of aluminum and its alloys in total energy expenditure can be found. The higher energy consumption of these materials compared to steel results from a fourfold increase in the unit energy consumption index of the material primary production, which for aluminum is $166.169 \mathrm{MJ} / \mathrm{kg}$, while for steel it is only $40.903 \mathrm{MJ} / \mathrm{kg}$.

Compared to the Mk1 model, the percentage share of energy inputs for steel, cast steel and cast iron in the Mk6 model decreased by $6.6 \%$ and by $8.5 \%$ for aluminum and its alloys (Fig. 3). A systematic increase in the environmental load associated with the use of other materials can be observed. For non-ferrous metals, the share of energy inputs was over two and a half times higher, while for plastics and rubber it was a three-fold increase.

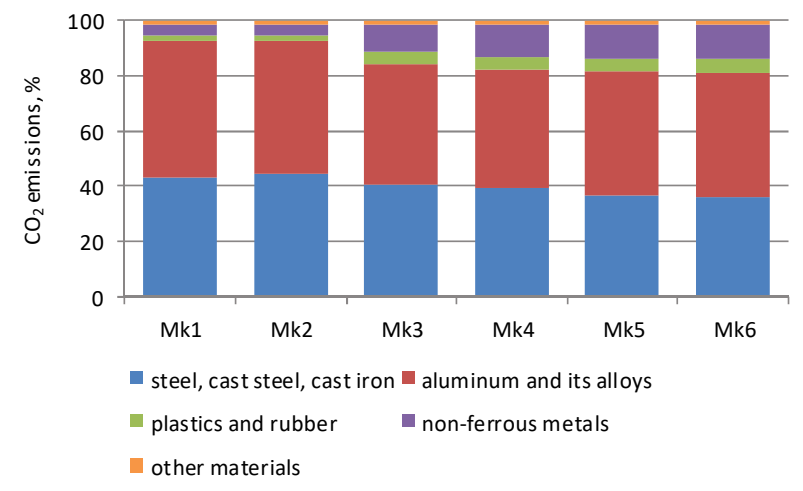

Fig. 4. Percentage share of $\mathrm{CO}_{2}$ emissions for the Volkswagen Golf engine and its equipment divided into materials
Such changes in energy inputs correspond to changes in carbon dioxide emissions. Percentage share of $\mathrm{CO}_{2}$ emissions between models Mk1 and Mk6 decreased by $7.4 \%$ for steel, cast steel and cast iron, and by $4.3 \%$ for aluminum and its alloys. For plastics and rubber there was more than two and half times increase in $\mathrm{CO}_{2}$ emissions, and for non-ferrous metals - almost three-fold increase in $\mathrm{CO}_{2}$ emissions.

\subsection{Impact of secondary production of materials (recycling)}

In the environmental assessment of materialssecondary production, a closed loop recycling scenario has been adopted where the size of the "environmental credit" of the se-condary production of the materials recovered from scrapped cars was determined as compared to the primary production of the materials. The amount of energy inputs (EI) and $\mathrm{CO}_{2}$ emissions related to the production of recycled materials was determined for the reuse and recycling indicators, which have come into effect since 2015 for all engines of vehicles withdrawn from use (RRR Directive, 2005). The results of the comparative assessment are shown in Figures 5 and 6.

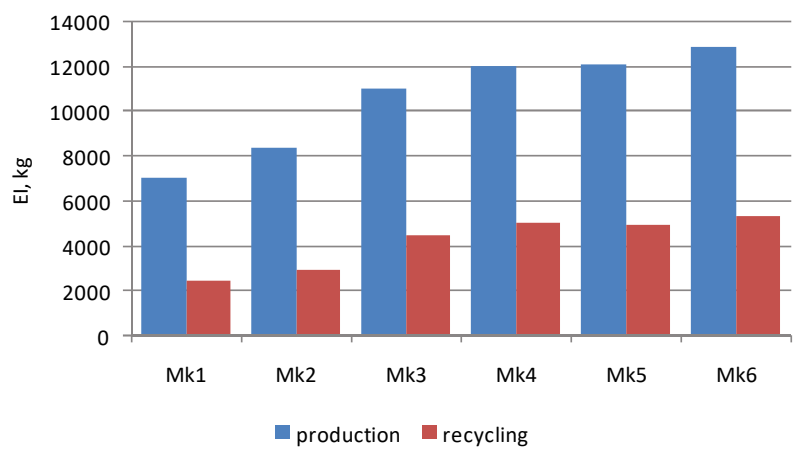

Fig. 5. Energy inputs for different scenarios of material production

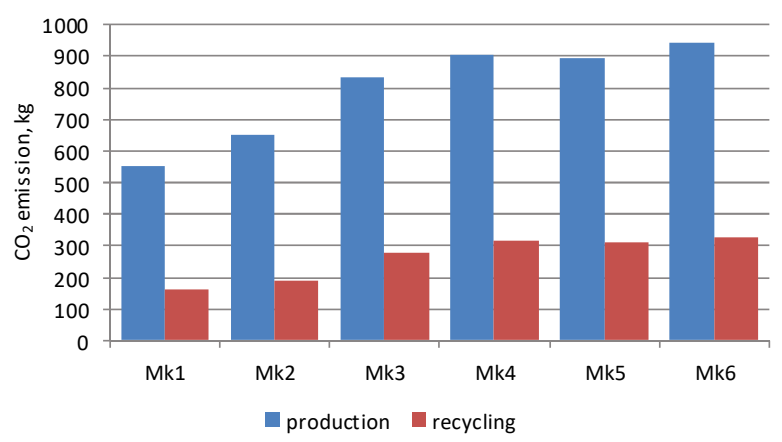

Fig. 6. $\mathrm{CO}_{2}$ emissions for secondary production

The results indicate the significant potential of recycling to reduce energy consumption and $\mathrm{CO}_{2}$ emissions during the production process. Despite the systematic increase in energy consumption and $\mathrm{CO}_{2}$ emissions for both primary and secondary production of materials, a noticeable reduction in environmental loads in the case of secondary production of materials is observed. At the same time, there is a reduction in the benefits of the use of recycled materials. This is the result of the growing use of plastics in 
the construction of engines whose recycling creates the greatest environmental problems.

\section{Conclusion}

The results presented in the paper show the environmental effects of changes in the composition of the material in the engines of Volkswagen Golf passenger cars in the past 30 years. The simplified LCA model of the engine presented in the paper shows the energy consumption and total $\mathrm{CO}_{2}$ emissions based on the mass of materials. Changes in the use of materials are a signal of the technological progress that has taken place in car construction in the past 30 years. The greatest progress was made with the introduction of the third-generation model. A number of changes to improve comfort and safety have been introduced. The price of these changes was to increase the weight of the whole car by about $18 \%$. At the same time, lightweight materials such as aluminum, plastics and rubber and nonferrous metals increased by about $4 \%$. So clear, compared to the predecessors, the increased use of these materials indicates the beginning of the implementation of a car weight reduction strategy, aimed at offsetting the effects of the changes in the design of not only the whole car but also the engine.

The selection of construction materials used in the construction of internal combustion engines of the Volkswagen Golf car has a significant impact on the level of their environmental impact. There is a tendency to reduce the share of steel, cast steel and cast iron while increasing the share of other materials. Systematic increase in the environmental burden associated with the use of other materials can be observed.

Based on the analysis, it can also be said that the recycling of materials can be an effective way to reduce the negative impact of internal combustion engines on the environment. The results indicate significant recycling potential in reducing energy consumption and $\mathrm{CO}_{2}$ emissions during the car engine production process. A significant reduction of environmental burden in the production of secondary materials from which the engine is built can be observed, despite the systematic increase of energy consumption and $\mathrm{CO}_{2}$ emissions.

\section{Nomenclature}

LCA life cycle assessment

$\mathrm{CO}_{2}$ carbon dioxide

EI energy inputs

Mk1 Volkswagen Golf I

Mk2 Volkswagen Golf II
Mk3 Volkswagen Golf III

Mk4 Volkswagen Golf IV

Mk5 Volkswagen Golf V

Mk6 Volkswagen Golf VI

\section{Bibliography}

[1] MERKISZ, J. Ekologiczne problemy silników spalinowych. Wydawnictwo Politechniki Poznańskiej. Poznań 1998.

[2] MERKISZ, J. Ekologiczne aspekty stosowania silników spalinowych. Wydawnictwo Politechniki Poznańskiej. Poznań 1995.

[3] International Organization for Standardization (ISO), 2006 a. 14040-Environmental Management. Life Cycle Assessment. Principles and Framework.

[4] International Organization for Standardization (ISO), 2006 a. 14040 - Environmental Management. Life Cycle Assessment. Requirements and Guidelines.

[5] KOWALSKI, Z., KĘDZIERSKA, D., NOWAK, A.K. et al. LCA analysis of processing of the zinc and lead ores in Trzebionka Mining Works. 10th Conference on Environment and Mineral Processing, VŠB-TU Ostrava, Czech Republic, Proceedings Part II, 22-24.06.2006, 105-115.

[6] KULCZYCKA, J. Ekologiczna ocena cyklu życia (LCA) nową techniką zarządzania środowiskowego. IGSMiE. Kraków 2001.

[7] PN-EN ISO 14040. Zarządzanie środowiskowe - Ocena cyklu życia - Zasady i struktura. Polski Komitet Normalizacyjny, czerwiec 2006 .
[8] PN-EN ISO 14040. Zarządzanie środowiskowe - Ocena cyklu życia - Wymagania i wytyczne. Polski Komitet Normalizacyjny, lipiec 2006.

[9] ELIASZ, J. Rozprawa habilitacyjna: Model całościowej, energetyczno-ekologicznej oceny technologii energetycznych. Technische Universität Dresden. Drezno 2002.

[10] GÓRALCZYK, M., KULCZYCKA, J. Ekologiczna ocena cyklu życia (LCA) - nową normą z rodziny ISO 14000. ProblemyEkologii. 2001, 4.

[11] HOOFTMAN, N., OLIVEIRA, L., MESSAGIE, M. et al. Environmental analysis of petrol, diesel and electric passenger cars in a Belgian urban setting. Energies. 2016, 9(2), 1-24.

[12] DOBROSZ, K., MATYSIAK, A. Tworzywa sztuczne w pojazdach samochodowych. Wydawnictwa Komunikacji $i$ Łączności. Warszawa, 1982.

[13] IDZIOR, M. Kierunki zmian materiałowychw motoryzacji w świetlewymogów ekologii. Motrol. 2007, 9.

[14] DANILECKI, K., MROZIK, M., SMURAWSKI, P. Changes in the environmental profile of a popular passenger car over the last 30 years - Results of a simplified LCA study. Journal of Cleaner Production. 2016, 141, 208-218.

[15] BIRAT, J., GUERIN, V., ROCCHIA, L., TUCHMAN, M. Ecodesign of automobiles basedon the environmental properties of body materials. SAE Technical Paper. 2004, 200401-0250.

\footnotetext{
Krzysztof Danilecki, DSc., DEng. - Faculty of Mechanical Engineering and Mechatronicsat West Pomeranian University of Technology in Szczecin. e-mail: Krzysztof.Danilecki@zut.edu.pl
}

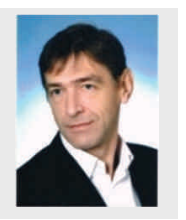

